\title{
SOCIOLOGY OF ORGANIZATIONS: POTENTIAL AND CHALLENGES
}

\author{
Sandro Serpa $^{1 *}$, Carlos Miguel Ferreira ${ }^{2}$ \\ ${ }^{1}$ University of the Azores, Faculty of Social and Human Sciences, Department of Sociology; Interdisciplinary Centre of \\ Social Sciences - CICS.UAc/CICS.NOVA.UAc; Interdisciplinary Centre for Childhood and Adolescence - NICA - \\ UAc, Ponta Delgada, Portugal \\ ${ }^{2}$ Interdisciplinary Centre of Social Sciences-CICS.NOVA, Polytechnic Institute of Castelo Branco, Estoril Higher \\ Institute for Tourism and Hotel Studies, 1069-061 Lisbon, Portugal \\ *sandro.nf.serpa@uac.pt
}

Article History: Received on $07^{\text {th }}$ January, Revised on $19^{\text {th }}$ February, Published on $19^{\text {th }}$ March 2019

\begin{abstract}
Purpose of this study: Sociology of Organizations, as a specialization, has maintained an indefinite status, competing with other disciplinary areas regarding the study of organizations. This paper seeks to contribute to the reflection about the potential and challenges faced by the Sociology of Organizations.
\end{abstract}

Methodology: For this purpose, a bibliographical research was carried out on this topic, complemented by our experience as sociologists in teaching and research on the organizational theme in some databases, such as Web of Knowledge, DOAJ, SCIELO, and institutional repositories.

Findings: It is concluded that the Sociology of Organizations can provide tools for the heuristic apprehension of the organizational phenomenon, either by mobilizing instruments of a more general sociology or by fostering a certain interdisciplinarity with other disciplinary areas that deal with this phenomenon.

Implications: However, this potential is generally obscured by greater visibility because it is perceived as more directly linked to the managerial phenomenon and seems to provide more illusorily practical solutions and universal recipes. It is necessary to recognize the complexity of the organizational phenomenon to advance its scientific knowledge.

Keywords: Sociology of Organizations, Administration, Management, Leadership, Organizations, Sociology.

\section{INTRODUCTION}

It is not unanimous to its conceptual clarification, which makes it difficult to delimit the object of study (Serpa, 2016; Mojic, 2017; Silva, 2007; Lammers, 1990). In this paper, an organization is considered as a structure and a process of action.

\section{Lima (2011) states:}

"A set of actors researching together with at least a minimum of coordination among themselves and with shared mutual expectations for the pursuit of goals assumed more or less internally and recognized externally (which are not necessarily the same), thereby influencing and being influenced by surroundings involving a certain period of time that materializes in a visible structure and constituting a totality with its own characteristics" (pp. 3257 3258);

"Therefore, the organization can be seen as a complex collective unit with a formal dimension and an informal dimension in which there is interaction between (individual and collective) actors with at least a minimum of coordination and reciprocal expectations that employ more or less different roles $\mathrm{m}$ the pursuit of goals set internally (not necessarily with the same degree of internal sharing) and generally recognized externally (which are not necessarily the internal goals) influencing and being influenced by the environment, producing for it, over time, characteristics that are both specific and dynamic" (p. 3258).

In spite of a certain academic and social recognition (Thoenig, 1998), which varies widely according to the social contexts and the epochs (Mutch, Delbridge, \& Ventresca, 2006; Mojic, 2017; Lammers, Cunha, \& Rodrigues, 2002; Filleau \& Marques-Ripoul1, 2002; Cunha, 2002), there are national and regional variations (Lammers 1990; Thoenig, 1998). Sociology of Organizations is sometimes considered as a sub-discipline of the sociology of work or industry (Mojić, 2017; Obradović, 1976).

Introducing Portugal as an example:

"It does not seem to exist, with its identity, a disciplinary field of organizational studies." 
Indeed, more than one multidisciplinary community of organization studies, such as psychology, sociology, company, economy, anthropology or others, seems to have a set of disciplines that define as objects of study (among others) for organizations, which normally go to the disciplinary analyzing of organizational phenomena. In order to use an organizational language, it is necessary go to the field to maintain a state of differentiation (disciplinary) with scarce mechanisms of integration (interdisciplinary). Chronological aspects, however, seem to point towards an evolution towards greater integration. Thus, a discussion of organizational studies as a multidisciplinary area is perhaps endowed with a language of its own, constructed from the diversity of those who practice it (Cunha, 2002, p.5).

The sociological specialization that functions simultaneously as a part of the general organization theory focuses on the organization as a whole and exhibits the distinction between organizations and social organizations and the characteristics of the sociological 'touch' (Lammers, 1990, p. 180).

Various socio-historical, economic, cultural, and political scientific conditions are present in the study of organizations, specifically through the mobilization of Sociology of Organizations (Pimentel, 2012; Obradović, 1976; Mojic, 2017). Obradović $(1976,24)$ gives us an old but very illustrative example of the ideological pressures that are present in the research on the sociology of organizations in the particular national context of former Yugoslavia, materialized in the study of three great problems: 1) Problems related to the participation in the decision-making process; 2) Distribution of power, responsibilities, and their correlates; 3 ) Effects of participation and distribution of power on various sociological and socio-psychological variables.

In the context described above, a sociology of organizations (and enterprise as a type of organization) will be feasible (Pimentel, 2012). What is the potential and challenges to be faced by the Sociology of Organizations? "Discussion" subdivided in "The Utility of Sociology of Organizations" and "Challenges of Sociology of Organizations" culminates in "Conclusion".

\section{METHODOLOGY}

1. This paper is guided by the following questions: What is the relevance of Sociology of Organizations is today as well as the challenges to be faced in the near future by Sociology of Organizations.

2. In order to fulfill this desideratum, the privileged technique to gather information on the topic under study was the collection and documentary analysis of articles that provided a significant contribution to answer the research questions. The collection was based on the consultation of the B-ON database of the Portuguese Foundation for Science and Technology (FCT) in Portugal, an electronic library resource, which includes databases of electronic scientific information such as Web of Knowledge, DOAJ, SCIELO, and institutional repositories (What is b-on ?, sd). A bibliographical research was conducted between February 1 and 4, through the search for the following expression / keyword, in the title: "sociology of organizations". This online bibliographic research was increased by the collection of complementary bibliographical material directly related to this issue.

\section{DISCUSSION}

Although a multi-paradigmatic one (Ferreira \& Serpa, 2017), sociology as a science: "studies the (dis) order of the social world, which deals with interactions, what results from interaction, and has implications in this interaction between humans, practices, representations, and values, inserting them in their social context" (Serpa \& Ferreira, 2018, 841).

The consideration that sociology is confirmed to organizations began to reveal itself in World War II, mainly in the United States. The branch of sociology that has been developing the debate on the vocation of sociology (that is, whether it should develop or not) lead to concrete applications? Human research is the mission of actions and is important in organizational practices. However, a sociological tradition is above all in the first perspective and does not cause problems to arise (Filleau \& Marques-Ripoull, 2002, p.20).

\section{Usefulness of Sociology of Organizations}

In the study of organizations:

"It has not yet been able to form a single body of doctrine, and still less can it aspire to the status of science. First and foremost, it consists of a set of theoretical instruments based on numerous disciplines, of which economics, sociology, administration and psychology are among the most important. This diversity of perspectives, even if partially incompatible, is in fact an indispensable condition for understanding the different issues within organizations, a broad and rich view is needed to grasp a reality complex" (Filleau \& Marques-Ripoull, 2002, 45). 
The Sociology of Organizations, useful as a scientific discipline (Ferreira \& Serpa, 2017), must present:

"Scientific knowledge may be considered as a set of verified and verifiable knowledge, obtained through a systematic process and demonstrated in a rigorous and controlled way. This rigor and control must be present both in the process (in the execution of a research) and in the product of a research (in its final result, such as an article, a book, a report, or a presentation, among others)" (Serpa \& Ferreira, 2018, p. 840).

One of the dimensions of Sociology of Organizations has an inherent sociological dimension (Thoenig, 1998). For example, sociologists see preferences as the outcomes of contracts and social and economic exchanges and not as motives for initiating them. Second, sociologists understand that preferences are directly related to social roles, and only indirectly to individuals who occupy them. The implications are that individuals have fluid preferences as they move between social roles and moreover, individuals have preferences about both modes of social and economic exchanges and about their outcomes (Scholten \& Skov, 2002, p.347).

Urteaga (2013) states:

"Understanding the rules and logic of the functioning of this collective life and the forms of cooperation gives rise to the object of the sociology of organizations" (p.153).

However, the formal and / or internal dimension is not enough to analyze organizations (Serpa \& Ferreira, 2019; Petkova, 2014).

Considering the company as an organization:

"The construction of a sociological theory of the company pre-supposes the company as a timeless, historical, technical, and economic apparatus, but that the company feeds on institutional, social, and cultural contexts of a certain era ... no there is sociological knowledge of the company without the admissibility of its internal autonomy" (Pimentel, 2012, p.6).

\section{Challenges of Sociology of Organizations}

"When the sociologist is called upon to intervene, a number of constraints emerge: the danger of being attached to a vision of overly temporal intervention, the pressure of it when the duration of the intervention is rigidly fixed, the expectation shared by the actors of a diagnostic intervention, the cognitive and methodological difficulties experienced by the sociologist / consultant to capture the organizational complexity" (Pimentel, 2012, p.161).

The difficulty in the institutionalized affirmation of Sociology of Organizations (Thoenig, 1998) is negative because it does not foster the development of the potentialities of this scientific discipline in situations, such as interdisciplinary collaboration (Serpa, Miguel \& Santos, 2017):

"The strength of sociology of organizations comes precisely from its ability to overcome the boundaries of its thematic field. ... this is not, despite certain attempts, a science of management. Their first vocation is not to offer technical solutions to the actors or to the leaders of the organizations, even if the knowledge that produces can lead to reflect on their practices and those of their collaborators and on the instruments at their disposal. Its object is, above all, the apprehension and understanding of the social forms and modes of cooperation that people use to carry out their actions" (Urteaga, 2013, p.174).

As Laville (2012) says, "It is necessary to reconstitute the concrete reality of the companies concealed by the standardized management procedures of the actors" (p.13). And this is in a context in which technology is embracing much of the social, cultural, and economic sectors with direct and indirect consequences in organizations (Serpa \& Ferreira, 2018, para.1).

For a better understanding of the organizational phenomena (necessarily complex) in the past, present, and future, the problematization and reflexivity that the Sociology of Organizations has in their patrimony can be decisive for the apprehension of phenomena, such as the ideological naturalization that can be promoted as organizations (Mutch, Delbridge, \& Ventresca, 2006; Ferraz, 2018).

\section{CONCLUSION}

Regarding the relevance of the Sociology of Organizations today and the challenges to be faced by it in the near future, it 
is verified that:

"The agreement of the researchers that we live today in the 'World of Organizations' points out to the relevance of the sociological analysis of social actors and social relationships within organizations, and consequently, the sociology of organization as a scientific discipline" (Mojic, 2017, p.27).

This factor does not prevent the need for the renewal of Sociology of Organizations (Pimentel, 2012; Urteaga, 2013) to better fulfill and assume its place of scientific discipline, despite the influence of sociology, different from an overly manageable look, always recognizing that there are no universally valid or easy-to-apply recipes (Filleau \& MarquesRipoull, 2002; Pollitt, 2009; Serpa \& Ferreira, 2019; Pimentel, 2012).

\section{ACKNOWLEDGEMENT}

University of Azores, Interdisciplinary Centre of Social Sciences-CICS.UAc/CICS.NOVA.UAc, UID/SOC/04647/2013, with the financial support of FCT/MEC through national funds and when applicable, co-financed by FEDER under the PT2020 Partnership Agreement.

The authors would like to thank the reviewers for their insightful comments and suggestions.

\section{REFERENCES}

Cunha, M. P e (2002). Estudos organizacionais em Portugal: o caso da psicologia organizacional. In Cunha, M. P. e \& Rodrigues, S. B. (Orgs). (2002). Manual de estudos organizacionais. Temas de psicologia, psicossociologia e sociologia das organizações [Handbook of organisational studies. Topics of psychology, psychosociology and sociology of organizations]. Lisboa: RH Editora. Pp. 3-21.

Cunha, M. P. e \& Rodrigues, S. B. (Orgs). (2002). Manual de estudos organizacionais. Temas de psicologia, psicossociologia e sociologia das organizações [Handbook of organisational studies. Topics of psychology, psychosociology and sociology of organizations]. Lisboa: RH Editora.

Ferraz, J. (2018). Sociology's Role in the Teaching of Organizational Behavior in Higher Education. The Case of Hospitality Management. Societies, 8(3), 51. https://doi.org/10.3390/soc8030051

Ferreira, C., \& Serpa, S. (2017). Challenges in the Teaching of Sociology in Higher Education. Contributions to a Discussion. Societies, 7(4), 30. https://doi.org/10.3390/soc7040030

Ferreira, C. M., \& Serpa, S. (2018). Society 5.0 and Social Development: Contributions to a Discussion. Management and Organizational Studies, 5(4). https://doi.org/10.5430/mos.v5n4p26

Filleau, M-G., \& Marques-Ripoull, C. (2002). Teorias da organização e da empresa: Das correntes fundadoras às práticas actuais [Organisation and company theories: From foundational currents to presente-day practices]. Oeiras: Celta Editora.

Lammers, C. J. (1990). Sociology of Organizations Around the Globe. Similarities and Differences Between American, British, French, German and Dutch Brands. Organization Studies, 11(2), 179-205. https://doi.org/10.1177/017084069001100202

Laville, Jean-Louis, "Prefácio", pp. xvii-xix in Pimentel, D. (2012). Sociologia da empresa e das organizações. Uma breve introdução a problemas e perspectivas [Sociology of de company and organisations. A brief introduction to problems and perspectives]. Lisboa: Escolar Editora.

Lima, L. C. (Ed.). (2011). Perspectivas de análise organizacional das escolas. Vila Nova de Gaia, Portugal: Fundação Manuel Leão.

Mojić, D. (2017). To whom, what for and how far is the sociology of organization still needed? Socioloski Pregled, 51(1), 3-27. https://doi.org/10.5937/socpreg1701003m

Mutch, A., Delbridge, R., \& Ventresca, M. (2006). Situating Organizational Action: The Relational Sociology of Organizations. Organization, 13(5), 607-625. https://doi.org/10.1177/1350508406067006

Obradović, J. (1976). Sociology of Organization in Yugoslavia. Acta Sociologica, 19(1), 23-35. https://doi.org/10.1177/000169937601900103

Petkova, I. (2014). Bureaucratic versus Non-bureaucratic Organization: Explaining Form, Function, and Change in New Forms of Organizing. Management and Organizational Studies, 2(1). http://dx.doi.org/10.5430/mos.v2n1p33 
Pimentel, D. (2012). Sociologia da empresa e das organizações. Uma breve introdução a problemas e perspectivas [Sociology of de company and organisations. A brief introduction to problems and perspectives]. Lisboa: Escolar Editora.

Scholten, M., \& Skov, J. (2002). A história inacabada de David e Golias; o comportamento humano e económico. In Cunha, M. P. e \& Rodrigues, S. B. (Orgs). (2002). Manual de estudos organizacionais. Temas de psicologia, psicossociologia e sociologia das organizações [Handbook of organisational studies. Topics of psychology, psychosociology and sociology of organizations]. Lisboa: RH Editora. Pp. 331-353.

Serpa, S., Ferreira, C. M., \& Santos, A. I. (2017). Fostering Interdisciplinarity: Implications for Social Sciences. International Journal of Social Science Studies, 5(12), 44. https://doi.org/10.11114/ijsss.v5i12.2775

Serpa, S. \& Ferreira, C. M. (2018). Sociological Problem and Social Problem: Contributions to a Discussion. Sociology and Anthropology, 6(11), 840-844. DOI: 10.13189/sa.2018.061104

Serpa, S. (2016). Organization as an Analytical Level for Investigation Organizational Culture. The Social Sciences. 11(13), 3257-3263. doi: 10.3923/sscience.2016.3257.3263. (Indexed: Agro Asia; World Agri. Database; MedLit; Scopus; ASCI-ACR). URL: http://medwelljournals.com/abstract/?doi=sscience.2016.3257.3263

Serpa, S., \& Ferreira, C. M. (2019). The Concept of Bureaucracy by Max Weber. International Journal of Social Science Studies, 7(2), 12. https://doi.org/10.11114/ijsss.v7i2.3979

Silva, D. V. e. (2007). Escola e lógicas de acção organizacional: contributos teóricos para uma análise sociológica da organização educativa. [School and organizational actions logics : theorise contributions for a sociology analyse of educative organizations], Avaliação e Políticas Públicas Em Educação 15(54), 103-126. https://doi.org/10.1590/s0104-40362007000100007

Urteaga, E. (2013). La sociología de las organizaciones: perspectivas alternativas. Revista Internacional de Organizaciones, 0(8), 151. https://doi.org/10.17345/rio8.151-176

Thoenig, J.-C. (1998). How Far is a Sociology of Organizations Still Needed? Organization Studies, 19(2), 307-320. https://doi.org/10.1177/017084069801900207 